Neth. J. agric. Sci. 17 (1969) : 92-98

\title{
A study on the suitability of some soils in Northern Surinam for Pinus caribaea var. Hondurensis
}

\author{
S. Slager ${ }^{1}$ and J. P. Schulz \\ Laboratory for Regional Soil Science, Wageningen, the Netherlands \\ Forest Service, Paramaribo, Surinam \\ Received 6 November 1968
}

\section{Introduction}

Over $80 \%$ of the country is under primeval neotropical rain forest. However, at this moment forest working is confined to the economically accessible forests that occur as a narrow northern belt edging the interior forest area. In the forest reserves, located in the 'forest belt', one of the measures adopted for sustained-yield management, is conversion of the greatly mixed climax forest into plantations of indigenous and exotic species (Schulz and Rodriguez, 1966).

In the silvicultural program of the Forest Service attention is concentrated on fastgrowing species for large-scale, rapid production of industrial wood. The Honduras Pine proved to be one of the most promising species for this purpose. Planting of this tree on an experimental scale was started in 1949. First pilot scale plantations date from 1956 and at the end of 1964 over 1800 hectares had been planted. Since 1964 expansion of the area was limited by financial necessities; from 1968 on the planting program will be recommenced, financed from the Five-Year Development Plan. Preparation of soil suitability maps, essential to planning of the expansion of the plantation area (5000 ha in the next five years), was undertaken by the Soil Survey Department. Interpretation of these maps in terms of yields to be expected from pine plantations, called for detailed morphological studies, the results of which are subject of this paper.

\section{Some data on environmental conditions in the region}

In Surinam three main regions can be recognised, viz:

1. Upland Region (the 'Interior');

2. Coastal Plain Region;

3. Coverlandscape Region.

The Upland Region, forming some $80 \%$ of the surface area of the country, varies in physiography from undulating to steep and rugged and lies at an elevation of 100 to some $1000 \mathrm{~m}$ above sea level. It is underlain by Crystalline Basement rocks of Pre-Cambrian age, belonging to the Guiana Shield (IJzerman, 1931; Montagne, 1964). The rocks mainly consist of deeply weathered gneiss, schist, granite, diorite and dolorite.

1 Advisor of the Soil Survey Department on behalf of the Netherlands Technical Assistance from 1966-1968. 
The Coastal Plain Region, an almost flat strip of marine alluvium, partly reclaimed for agriculture, is subdivided into the Old Coastal Plain (Coropina series, Pleistocene) and the Young Coastal Plain (Demerara series, Holocene). The landscape is dissected by rivers, bordered by fluviatile and fluviomarine deposits. The Coastal Plain Region consists of heavily textured clay soils, locally with superimposed sand or shell banks. The Coverlandscape forms a zone of flat to undulating forest land and savanas between the two above mentioned regions. Its elevation varies from about $50 \mathrm{~m}$ in the south to $6 \mathrm{~m}$ in the north. Its width varies from $70 \mathrm{~km}$ on the Corantine River to $10 \mathrm{~km}$ on the Marowine River. The zone wherein up to now little agriculture is practised, and where the main forestry undertakings are carried out, is built up from 'islands', a few to some tens of kilometres in diameter, separated from each other by broad river valleys. Each 'island' is dissected by many creek valleys, varying from shallow gullies to $15 \mathrm{~m}$ deep valleys (van der Eijk, 1957). Most of the Coverlandscape consists of well-drained to excessively drained land, with marshes and swamps bordering creeks and rivers.

The sediments of the Coverlandscape are unconsolidated and vary from coarse sand to sandy loam, with heavier textured sediments along the creeks and rivers. The light and medium textured deposits, which were labelled Coesewijne deposits (Montagne, 1964), were laid down in late Tertiary times during a denudation cycle of the Crystalline Basement (Roose and Chéroux, 1966). Most authors (e.g. Heyligers, 1963) consider the rather coarse sandy deposits as continental sediments. X-ray diffraction of the sediments shows only quartz and kaolonite (Montagne, 1964). Mineral assemblages show less than $1 \%$ of weatherable minerals (Heyligers, 1963).

Since the Tertiary the Coverlandscape has undergone periods of erosion and of deposition of younger sediments (Coropina and Demerara Series, partly filling the river valleys), alternating with periods of soil formation.

The following chapters only deal with soils developed in the Coesewijne deposits of the Coverlandscape. In the area under consideration the climate is characterized by the following data, viz: mean annual rainfall $2200 \mathrm{~mm}$; two or three months per year with less than $100 \mathrm{~mm}$ precipitation; mean annual temperature $27^{\circ} \mathrm{C}$, with very small daily and monthly variations.

The original vegetation of the sites, ranging from semixerophytic to mesophytic (high tropical lowland) forest, was cleared mechanically before planting the pines.

\section{Soil classification}

The soils developed in the Coesewijne deposits of the Coverlandscape belong to three orders, viz Entisols, Spodosols and Oxisols (U.S. Soil Survey Staff, 1960, 1967).

The Entisols include the deeply bleached coarse sand soils with spodic B-horizons, the upper boundary of which does not begin until several metres below the soil surface. They occur in plateau position and as colluvium on slopes and were classified as Typic Quartzipsamments. To the Entisols also belong very light textured non-bleached soils with yellowish, brownish or reddish B-horizons, which, however, do not meet the requirements of any diagnostic subsurface horizon. They were classified as Oxic Quartzipsamments.

The Spodosols among the investigated soils fall apart into two suborders. Few belong to the Aquods, while the others all are Orthods. Some of the Orthods are characterised by a fragipan and were classified as Fragiorthods. Most of the Orthods 
studied meet the requirements of the Haplorthods, except the temperature criteria. They were tentatively named as Troporthods.

All other soils developed in the Coesewijne deposits of the Coverlandscape are Oxisols and not, as was generally accepted hitherto in Surinam, partly Ultisols and partly Inceptisols. Thin-section analysis proved that none of these soils have any clay illuviation. Cation exchange capacity values range from 2 to 4 meq per $100 \mathrm{~g}$ of clay. These Oxisols belong to the suborder of the Orthox. They fall apart into two great groups, viz the Umbriorthox and the Haplorthox. Within the Umbriorthox only Psammentic subgroups were found. Within the Haplorthox many Psammentic and a few Aquic and Typic subgroups were observed.

\section{Soil suitability for $\mathbf{P}$. caribaea}

\section{Methodology}

Some 20 soil profiles were described within permanent yield plots in pine plantations ${ }^{2}$. Another 30 profiles were recorded in detail in various locations in the Coverlandscape, outside the existing plantations, in order to evaluate the amplitude of each of the described soil types. Excluded from this study were those soils (within the Coverlandscape, but not belonging to the Coesewijne deposits) which were known to be completely unsuitable for the growth of Honduras Pines.

The profiles were described according to the criteria given by the U.S. Soil Survey Staff $(1960,1962,1967)$, supplemented with data on soil structure and porosity (cf. van der Plas and Slager, 1964; Slager, 1964, 1966) ${ }^{3}$.

Productivity classes of pine were estimated from height growth; development of upperheight ${ }^{4}$ as measured in the yield plots has been taken as an index for the elaboration of a provisional site-classification (cf. Voorhoeve and Schulz, 1968).

Soil properties as shown by the profile descriptions were compared with the height classes into which the stands fell and soil types were recombined and reduced to units which can easily be recognised during a soil survey.

\section{Suitability classification}

In this paragraph growth results will be compared with soil properties. The growth results are indicated as classes, ranging from 1 to 5 , in which Class 1 corresponds with the highest yields of $P$. caribaea. In order to group together soils with similar properties and to separate them from soils with other properties, the classes were subdivided. It should be stressed, however, that soils in different subclasses of the same main class have the same suitability.

Class 1. Well-drained, medium to light textured (colluvial) Coesewijne deposits in a weakly sloping position at the lower end of slopes near creeks (Psammentic Umbriorthoxes). Characteristics associated with wetness occur between 100 and $125 \mathrm{~cm}$;

2 The methodology of permanent increment/thinning plots applied by the Surinam Forest Service, and the calculation of stand characteristics from periodic measurements are described by Schulz and Rodriguez (1967) and by Voorhoeve and Schulz (1968).

3 Mimeographed copies of the original report, including detailed soil descriptions, are available on request from the Surinam Forest Service or from the Soil Survey Department of the Ministry of Mines, Forests and Lands, Paramaribo, Surinam.

4 'upperheight' $=$ mean height of the 100 tallest trees per ha. 


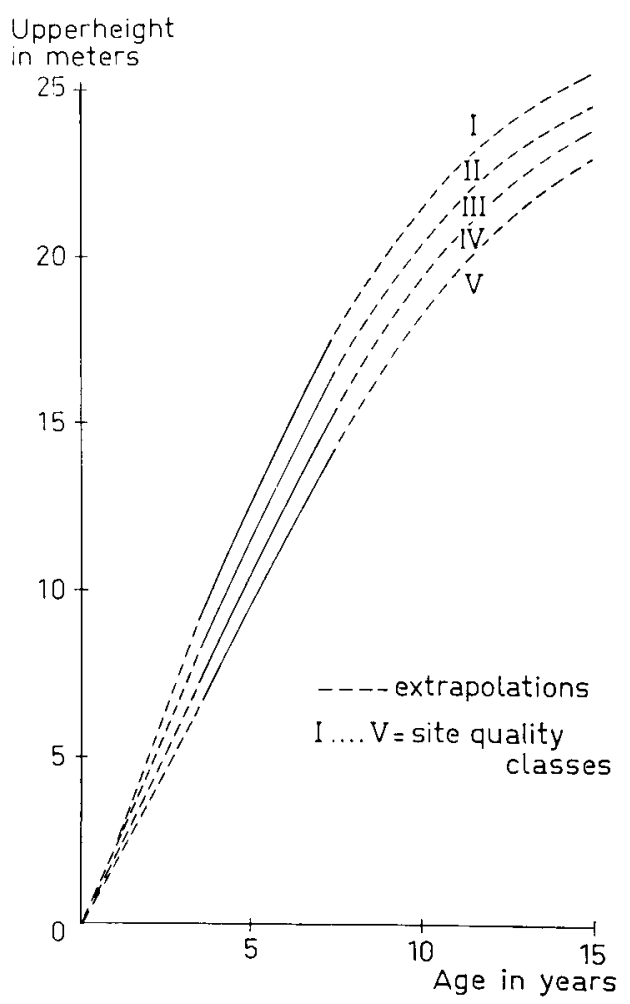

Fig. I Preliminary site-quality classification of Pinus caribaea var. hondurensis based on measurements of upperheight in 40 permanent yield/ thinning plots

sandy loam; 50-100 $\mathrm{cm}$ thick layer with common to much organic matter; intermediate bioporosity.

Class 2.1. Somewhat excessively drained, light textured Coesewijne deposits, in a weakly sloping position, mostly halfway between plateau and creek (Troporthods). No characteristics associated with wetness within $2 \mathrm{~m}$; loamy coarse sand; 100-150 cm thick layer with common to much organic matter; intermediate bioporosity.

Class 2.2. Well-drained, light (to medium) textured Coesewijne deposits in a weakly sloping position, mostly halfway between plateau and creek (Troporthods and Psammentic Umbriorthoxes). No characteristics associated with wetness within $2 \mathrm{~m}$; (coarse) sandy loam; $50-100 \mathrm{~cm}$ thick layer with common to much organic matter; intermediate bioporosity.

Class 2.3. Well-drained to somewhat excessively drained, light textured, Coesewijne deposits, mostly halfway between plateau and creek (Fragiorthods). No characteristics associated with wetness within $2 \mathrm{~m}$; sand; 50-100 $\mathrm{cm}$ thick layer with common to much organic matter; intermediate bioporosity; slightly permeable pan at about $1 \mathrm{~m}$ below the soil surface.

Class 3.1. Somewhat excessively drained, light textured, non-bleached Coesewijne deposits in a weakly sloping to flat position at the upper end of slopes (Oxic Quartzipsamments). No characteristics associated with wetness within $2 \mathrm{~m}$; (slightly) loamy sand; 50-100 $\mathrm{cm}$ thick layer with little to common organic matter; low bioporosity. 
Class 3.2. Well-drained, light to medium textured Coesewijne deposits in a weakly sloping position, halfway between plateau and creek (Psammentic Umbriorthox). No characteristics accociated with wetness within $2 \mathrm{~m}$; (coarse) sandy loam; $50 \mathrm{~cm}$ thick layer with little to common organic matter; low bioporosity.

Class 4.1. Excessively drained, very light textured, deeply bleached Coesewijne deposits at the lower end of slopes with lateral water influx from higher parts (Typic Quartzipsamments). No characteristics associated with wetness within $2 \mathrm{~m}$; coarse sand throughout the profile; less than $50 \mathrm{~cm}$ thick layer with organic matter; very low bioporosity.

Class 4.2. Excessively drained, very light textured, non-bleached Coesewijne deposits at the upper end of slopes (Oxic Quartzipsamments). No characteristics associated with wetness within $2 \mathrm{~m}$; (slightly loamy) coarse sand; $50-100 \mathrm{~cm}$ thick layer with common organic matter; low bioporosity.

Class 5. Excessively drained, very light textured, deeply bleached Coesewijne deposits in a completely flat position (white sand plateau soils) (Typic Quartzipsamments). No characteristics associated with wetness within $2 \mathrm{~m}$; coarse sand throughout the profile; less than $50 \mathrm{~cm}$ thick layer with little organic matter; very low bioporosity.

\section{Discussion}

As has been stated before, the suitability classification results from a comparison of profile descriptions and measurement of productivity. This already is a simplified way of comparing soils in the field with yield estimates. But even the comparison of 20 profile descriptions with yields is difficult. Therefore, attention was given only to a number of items of the profile descriptions. A problem to be solved was to decide which items were important.

We soon detected that Pinus reacts in a similar way to soil properties as most deeprooting trees (cf. Slager, 1966). This implied that the growth of Pinus is positively correlated with the amounts of plant-available moisture, oxigen and plant nutrients in the soil and with rootable soil depth.

The amount of plant-available moisture in the soil depends on the amount of fine inorganic and organic particles in the soil (moisture retention), on the watertable and its fluctuations (capillary rise) and on possible lateral water influx (on the lower part of slopes).

The amount of plant-available nutrients in soils as poor as those under consideration almost completely depends on the amount and nature of the organic fraction in the soil.

The amounts of oxigen and carbon dioxide are correlated both with the watertable and with porosity. Well drained and excessively drained soils in the areas under consideration rarely are subject to lack of oxigen or excess of carbon dioxide.

Rootability depends on many of the above mentioned factors. A soil is not rooted, however, if pores are not present, which are essential to reach the stored moisture and mineral reserves (Slager, 1966).

In conclusion the following items would be enough to work with in the field:

1. Influence of groundwater, expressed for each soil in the depth at which 'characteristics associated with wetness' (U.S. Soil Survey Staff, 1960) occur, together with possible occurrence of lateral water influx;

2. Texture, using classes defined by the U.S. Soil Survey Staff (1962); 
3. Organic matter distribution, based on field estimations;

4. Distribution of biopores (cf. Slager, 1966), based on countings in the field.

Whereas data for item 1 are expressed in a simple figure, those for items 2,3 and 4 are difficult to handle. For the latter items graphs were drawn which were smoothed as far as possible. For most of the soils it was thus possible to obtain a set of four of five numbers, together corresponding with yield results. Unknown was the 'weight' of each item. In practice, however, we were able to predict yield results for most of the soils in terms of high, medium and low.

Since none of the factors included is typical for $P$. caribaea, it seems worthwhile to try and use the above explained method also for suitability schemes for other trees (citrus, oil-palm etc.). Further, it seems worthwhile to include studies like the present one in large-scale soil surveys; such studies are relatively cheap and not time-consuming, and they give the survey a greater applicability.

The following remarks on the suitability scheme illustrate the contribution ('weight') of the various soil factors to the yield of $P$. caribaea. The high suitability of soils in Class 1 for $P$. caribaea is supposed to result mainly from water-supply via capillary rise.

The soils of Class 4.1 and Class 5 cannot be distinguished from each other morphologically. The higher suitability of the former soils results from their position at the lower end of slopes with lateral water influx.

Soils of Classes 2.1 and 2.2 have the same suitability. They differ both in texture and in thickness of the layer with organic matter, all other properties being the same. A thicker layer with the same amount of organic matter seems to compensate a somewhat coarser texture.

In general, from Classes 2 to 5 in increasing degree textures become coarser, while layers with organic matter become thinner and organic matter content and bioporosity lower. To some extent each of these factors can compensate each other.

\section{Acknowledgments}

The authors are indebted to the Director of the Department of Mines, Forests and Lands for the permission to publish this study.

The authors wish to express their indebtness to Mr W. Chr. Saro, who participated in collecting the field data and in preparing the original report.

\section{References}

Annual Reports of the Surinam Forest Service.

Eijk, J. J. van der, 1957. Reconnaissance Soil Survey in northern Surinam. Thesis, Wageningen.

Montagne, D. G., 1964. New facts on the geology of the 'young' unconsolidated sediments of northern Surinam. Geologie en Mijnbouw 43: 499-515.

Plas, L. van der \& Slager, S., 1964. A method to study the distribution of biopores. In: A. Jongerius (Ed.), Soil Micromorphology. Elsevier, Amsterdam, p. 411-419.

Roose, E. \& Chéroux, M., 1966. Les sols du basin sédimentaire de Côte d'Ivoire. Cahiers ORSTOM, Serie Pédologie 4 (2), p. 51-92.

Schulz, J. P. \& L. Rodriguez, P., 1966. Plantaciones forestales en Surinam. Revta for. 14: 5.

Schulz, J. P. \& L. Rodriguez, P., 1967. Establecimiento de parcelas para estudio de rendimiento en plantaciones forestales de $C$. lusitanica, $P$. radiata y $P$. pseudostrobus en los andes venezolanos. Revta for. Venez. $15: 21$. 
Slager, S., 1964. A study of the distribution of biopores in some sandy soils in the Netherlands. In: A. Jongerius (Ed.), Soil Micromorphology. Elsevier, Amsterdam, p. 421-427.

Slager, S., 1966. Morphological studies of some cultivated soils. Thesis. Pudoc, Wageningen,

U.S. Soil Survey Staff, 1962. Soil Survey Manual USDA. Handbook 18, pp. 503.

U.S. Soil Survey Staff, 1960-1967. Soil Conservation Service. Soil classification, a comprehensive system. 7th Approximation and 1967-supplement.

Voorhoeve, A. G. \& Schulz, J. P., 1968. Permanent yield/thinning plots - a 'must' in forest plantations. Reports Ministry of Mines, Forests and Lands, Paramaribo, Surinam.

IJzerman, R., 1931. Outline of the geology and petrology of Surinam (Dutch Guiana). Thesis, Utrecht.

\section{Summary}

Sixteen years ago experiments were started in Surinam with Pinus caribaea. Since pilot scale plantations have shown promising results, a pine planting program of 5000 ha in total is planned for the next 5 years. Consequently, a stratification of planting sites according to suitability classes was imperative. In order to obtain insight in the interrelation of soil properties and yield of $P$. caribaea a soil morphological study was performed in and around permanent yield plots in existing plantations. Some 50 pits were described, all situated in the Coverlandscape. This gently sloping landscape includes a variety of light to medium textured, chemically poor, generally free draining soils, developed in unconsolidated sediments of Tertiary continental origin. The soils belong to the orders of the Entisols, Spodosols and Oxisols.

Soil properties found to be correlated with yields of $P$. caribaea are:

1. Influence of groundwater (capillary rise, lateral water influx);

2. Texture (moisture retention);

3. Organic matter (moisture retention, supply of plant nutrients);

4. Biopores (rootability).

Combinations of these soil properties are compared with production and soil suitability classes are defined and discussed.

\section{Resumen}

Desde 16 anos atras se iniciaron en Surinam algunos experimentos preliminares con Pinus caribaea. Una vez que estos demonstraron ser promisorios para la reforestación a gran escala. El objetivo inmediato, para cumplir este propósito, fué la plantación basada en la estratificación de los sitios de plantación segun su capacidad productiva. Para conseguir una mayor información sobre las relaciones entre las propiedades de los suelos y el rendimiento de $P$. caribaea, se realizó, en parcelas permanentes dentro de las plantaciones existentes, un estudio pedológico desde el punto de vista morfológico.

En total se describieron 50 calicatas, las que se localizaron en los sitios de orígen geomorfológico denominado 'Paisaje superpuesto'. De un modo general, las características fisiograficas de estos suelos ofrecen una amplia variación, desde ligero à mediano. Son pobres en sustancias nutritivas y por lo general son bien drenados. Estos suelos se desarollaron a partir de sedimentos inconsolidados de orígen terciario continental, y pertenecen al orden de los Entisoles, Spodosoles, y Oxisoles.

Las propiedades de los suelos, que demostraron estrecha correlación con el rendimiento de $P$. caribaea, fueron:

1. Influencia del agua de fondo (movimiento capilar, influjo del agua lateral);

2. Textura (retención de la humedad);

3. Materia orgánica (retención de humedad, suplencia de nutrientes para las plantas);

4. Bíoporos (capacidad de penetración de las raíces).

Las combinaciones de estas propiedades fueron comparados con los resultados del rendimiento, y asimismo se definieron y analizaron, desde el punto de vista de adaptación para $P$. caribaea, las diferentes clases de suelo. 